\title{
THE STANDARD THEORY OF ADMINISTRATIVE UNLAWFULNESS*
}

\section{ABSTRACT}

According to the standard theory of administrative unlawfulness an act which is public law unlawful is, for that reason, invalid and of no effect in law. In this article I suggest that the theory ought to be rejected. I begin by outlining the standard theory as well as noting its endorsement by the Supreme Court in the case of Ahmed (no 2). Having in the main part of the paper criticized the theory, I move to lay out an alternative: that unlawfulness signals not the invalidity of an administrative act but a duty on the part of the court to invalidate it. Noting that the alternative rests upon what appears to be a paradox - that unlawful administrative action may nonetheless have legal effect - I try to show why it is more apparent than real. Finally, I return to the decision in Ahmed (no 2).

\section{KEY WORDS}

Legal Theory; Jurisprudence; Administrative Law; Authority; Invalidity

Word count (including footnotes): 11,729

\section{INTRODUCTION}

On the 7 March 1958 a watch committee convened by the local police authority dismissed Charles Ridge from his position as Chief Constable of the Borough of Brighton. Ridge had previously been charged with obstructing the course of justice and although he was cleared of that offence the trial judge had been very critical of his behaviour. Subsequent to this and without first granting him a hearing the committee removed Ridge from his position. But as the House of Lords famously held natural justice demands that a body in the position of the watch committee allow an individual subject to their jurisdiction the capacity to respond prior any decision being made which would rescind their right to employment. What did this mean for the legal status of the committee's decision? Lord Reid was clear: "a decision given without regard to the principles of natural justice...is void." 1 The committee's purported dismissal was, in the language he would later use to describe all forms of administrative unlawfulness, a "nullity" and consequently of no existence in law. ${ }^{2}$ I will call this view of the nature of unlawful administrative acts the view that an act which is public law unlawful is for that reason invalid and without legal effect - the standard theory of administrative unlawfulness. In what follows I suggest that it ought to be rejected.

\footnotetext{
* Thomas Adams, Corpus Christi College, Cambridge. I would like to thank Hasan Dindjer, Mark Elliott, David Feldman and Fred Wilmot-Smith for their comments. ${ }^{1}$ Ridge v Baldwin [1964] A.C. 40, 80

2 Anisminic v Foreign Compensation Commission [1969] 2 A.C. 147, 153
} 
In section two I introduce the standard theory, making clear how it depends upon an intuitive connection from the concept of unlawfulness through to the concept of invalidity. This, I explain, suggests a close analogy as between public law and private law powers. Section three outlines the recent judgment of the Supreme Court in Ahmed (no 2) and the way in which the court's endorsement of the standard theory affected its reasoning. ${ }^{3}$ In sections four and five I detail two problems for the theory, the former having to do with the effect of unlawful administrative action on rights and obligations prior to a court declaration of unlawfulness and the latter having to do with the effect of time limit and ouster clauses. In each case the difficulty stems from the way in which the standard theory holds us to the notion that unlawful administrative decisions have, from the start, no existence in law. In section six I lay out an alternative: that unlawfulness signals not the invalidity of a particular administrative act, but a duty on the part of the court to invalidate it. As such unlawful administrative action has the legal effect claimed for itself unless and until set aside by a competent court. Noting that the alternative rests upon what appears to be a paradox - that unlawful administrative action may nonetheless be legally valid - I try to show, in section seven, why it is more apparent than real. Finally, I return to the decision in Ahmed (no 2) and the broader question of discretion in the face of administrative unlawfulness.

\section{THE STANDARD THEORY}

The decision of the watch committee was unlawful because it had failed to comply with the rules of natural justice, those principles of procedural fairness that the law imposes upon administrative decision-making. But there are many reasons why an administrative act might be held to be unlawful. Certain of these have to do with constraints imposed by the common law, such as the duty to honour the legitimate expectations of those subject to public power and the requirement that decisions should be rational in the Wednesbury sense. ${ }^{4}$ Others have to do with the structural limits of the powers of administrative agencies: their jurisdiction under statute and prerogative, the purposes for which they may exercise their powers and the sideconstraints imposed by the Human Rights Act. ${ }^{5}$

What is the legal consequence of a failure to comply with such requirements? Wade and Forsyth follow Lord Reid. An unlawful administrative act is, they suggest, "a nullity, utterly without existence or effect in law... Errors such as bad faith, wrong grounds, and breach of natural justice all necessarily involve excess of jurisdiction

\footnotetext{
${ }^{3}$ Ahmed \& Ors v HM Treasury (no 2) [2010] UKSC 5, [2010] 2 W.L.R. 378

${ }^{4}$ Associated Provincial Picture Houses Ltd. v Wednesbury Corporation [1948] 1 K.B. 223

${ }^{5}$ In this and in what follows I assume against the ultra-vires theory of judicial review, an understanding on which all conditions on the lawfulness of administrative action in the statutory context owe themselves ultimately to the intentions of the legislature. For the best defence of that view see M. Elliott, The Constitutional Foundations of Judicial Review (Oxford 2001)
} 
and therefore nullity." 6 Mark Elliott echoes these remarks. An unlawful administrative act is, he argues, "invalid simply by virtue of its unlawfulness." This much is taken to follow automatically "once it is recognized that jurisdiction is... the principle around which administrative law is organized."7

Two elements of the conception are worth emphasizing. The first concerns the ontological status of unlawful decisions. Notice that according to the standard theory the fact of unlawfulness itself determines the invalidity of the relevant administrative act: such a decision is "invalid simply by virtue of its unlawfulness." 8 It is not, in other words, only in the aftermath of the court's judgment that the unlawful act should be understood to have no effect in law; the notion is that it never did. So when, for example, the watch committee attempted to dismiss Ridge from his position as police commissioner their decision, according to the standard theory, did not achieve this result. Because a condition of the committee lawfully dismissing him was that it give him a hearing, so in failing to do so the watch committee never actually exercised its power to fire Ridge. It only appeared to do so.

What motivates this aspect of the standard theory? The connection is drawn between the concept of unlawfulness and the concept of invalidity, where the former is taken to imply the latter. Forsyth makes the point:

...the obvious way in which the distinction between the lawful and unlawful is expressed is in the proposition that a decision maker who decides unlawfully, does an act which he has no power in law to do; that act is thus in law no act at all. It is invalid or simply void. ${ }^{9}$

Because an unlawful act is beyond the powers of the decision maker so the invalidity of that act is understood to follow as a natural consequence, an invalid decision being a decision that an individual has no power to make.

An analogy might be drawn with the exercise of private power. If a contract of employment stipulates a number of conditions on the exercise of a power of dismissal then each of those will have to be satisfied in order for the employer to be

${ }^{6}$ H.W.R. Wade and C.F. Forsyth, Administrative Law (11th ed., Oxford UK 2014) 247 citing in support Anisminic v Foreign Compensation Commission [1969] 2 A.C. 147 and Ridge v Baldwin [1964] A.C. 40. Further support for the standard theory can be found in Director of Public Prosecutions v Head [1959] A.C. 83, 104 as per Lord Somervell (although cf. Lord Denning in dissent) and Boddington v British Transport Police [1999] 2 A.C. 143, 153-155 as per Lord Irvine (although cf. 164 as per Lord BrowneWilkinson). See also P.P. Craig, Administrative Law (8th ed., London 2016), 733 7 M. Elliott, J. Beatson and M.H. Matthews, Beatson, Matthews and Elliott's Administrative Law : Text and Materials (4th ed., Oxford 2010), 79, 81 8 Ibid. 79. See, on this point, Anisminic v Foreign Compensation Commission [1969] 2 A.C. 147 pp. $169-171$ as per Lord Reid ${ }^{9}$ C.F. Forsyth, 'The Metaphysics of Nullity' in W. Wade and I. Hare (eds), The Golden Metwand and the Crooked Cord: Administrative Law Essays in Honour of Sir William Wade QC (Oxford 1998), 142 
able to exercise that option. In this way the conditions on the exercise of the power are also conditions on the existence of the type: a legally effective decision dismissing the employee. What the standard theory suggests is that the same is true in the case of public powers. Conditions on the lawful use of administrative power are conditions on the existence of valid decisions.

A further point follows from this aspect of the standard theory. The court, when determining that the administration has acted unlawfully, does not set aside or quash an otherwise effective decision, it declares that there never existed any such decision. So Mark Elliott says: "quashing unlawful measures merely demonstrates but does not procure - their invalidity. They are invalid because they are unlawful, not because they have been quashed." 10 Given that the decision of the watch committee was invalid from the start, so the decision of the House of Lords to quash it described but did not constitute its invalidity. ${ }^{11}$ It was as much of a dead letter at the moment it was made as when the court came later to perform its burial rights. ${ }^{12}$

These, then, are the two central features of the standard theory: its ontological aspect, which draws a connection from the concept of unlawfulness through to the concept of invalidity, and the implied role for the court, as a status-quo preserving institution rather than active agent in the context of administrative unlawfulness. Before moving to assess the theory I want to note its effect on the judgment of the Supreme Court in the recent case of Ahmed (no 2).

\section{SUSPENDING JUDGMENT}

The Ahmed saga concerned the legal status of two orders of the UK government which made provision for asset freezing. The orders were enacted under the United Nations Act 1946 as part of an attempt to implement a series of UN Security Council resolutions. These resolutions, largely passed in the aftermath of $9 / 11$, required that restrictions be placed on the property of a number of people allegedly linked with terrorist activity. In Ahmed (no 1) the Supreme Court decided that the government's orders were unlawful. ${ }^{13}$ The first of these - the Terrorism Order - was held to be unlawful because it employed a standard of reasonable suspicion for determining whether an individual could be subject to asset freezing measures, whereas the

10 M. Elliott, 'The Legal Status of Unlawful Legislation' [2013] Public Law for Everyone. See further Secretary of State for the Home Department $v$ JJ and others [2007] UKHL 45, [2008] 1 A.C. 385, at [25]-[27] as per Lord Bingham and Ahmed (no 2) [2010] UKSC 5, [2010] 2 W.L.R. 378, at [4]

11 See Ridge v Baldwin [1964] A.C. 40, 80 as per Lord Reid

12 For discussion of this implication of the standard theory see ibid., 92 as per Lord Evershed. The analogy with contract also helps to motivate this aspect of the picture. When a court rules that a party has failed to meet a condition on the exercise of a power in a contract it is, if accurate, issuing a decision which describes an existent state of affairs. The court is not making it the case there is no legally effective exercise of private power, it is authoritatively affirming that this is so.

${ }^{13}$ Ahmed \& Ors $v$ HM Treasury [2010] UKSC 2, [2010] 2 A.C. 534 
original Security Council resolution on which it was based had employed a higher standard of proof. The order was therefore ultra vires the United Nations Act which empowered the government to give effect to, but not go beyond, the requirements of Security Council resolutions. The second - the Al-Qaeda Order - was held to be unlawful because it made no provision for procedural fairness, thereby depriving those designated under it of access to an effective mechanism by which they could challenge their listing and the restriction on rights that this entailed. The Supreme Court moved to quash both orders.

In Ahmed (no 2) the government asked the court to pause. ${ }^{14}$ They wanted the Supreme Court to suspend the effect of its first judgment until new measures could be put in place that would lawfully freeze the assets of those designated under the orders. If there were a gap in time as between the efficacy of the original measures and the new regime the government feared that those who had been designated would take the opportunity to move their resources beyond the reach of the state.

What was the appropriate response to the government's request? Lord Phillips began by reiterating orthodoxy. "The problem with suspension in this case", he said "is... that the court's order, whenever it is made, will not alter the position in law. It will declare what that position is." 15 Because both the Terrorism and Al-Qaeda orders were unlawful they were invalid from the start. As such, the object of quashing them could only be to make "quite plain that [which is already] the case." 16

What did this imply about legitimacy of an order suspending the effect of the court's judgment? Because the court in quashing the orders would not affect their legal status, so an order suspending the effect of its judgment would itself make no difference to the situation. Both orders were invalid by virtue of their unlawfulness and so the Supreme Court's judgment, whether suspended in its effect or given effect to immediately, would not change this. In such circumstances:

...the effect of suspending the operation of the order of the court would be, or could be, to give the [wrong] impression. It would suggest that, during the period of suspension of the quashing orders, the provisions to be quashed would remain in force. ${ }^{17}$

That is, whilst an order suspending the effect of the court's judgment would not provide the measures in question with interim validity it could give the impression that they remained legally effective for the period in question. This, Lord Phillips suggested, would likely influence the behaviour of third parties, in particular the banks, who had acted on the supposition of the validity of the government's orders. Given that the probable effect of granting such an order would be to mislead these

\footnotetext{
14 Ahmed (no 2) [2010] UKSC 5, [2010] 2 W.L.R. 378

15 Ibid. at para. [4]

16 Ibid. at para. [4]

17 Ibid. at para. [5]
} 
bodies, Lord Phillips concluded, so the court "should not lend itself to a procedure that is designed to obfuscate the effect of its judgment."18

Here we can see the two aspects of the standard theory at work. First the ontological element: both the Terrorism Order and the Al-Qaeda Order were unlawful and for that reason "of no effect in law." 19 Second, the role of the court in quashing these instruments would not be to invalidate otherwise legally effective decisions but to demonstrate that which is already true, i.e. that the orders were always invalid. With these two elements in place the question became: should the court issue a decision, the consequence of which could only be to give the misleading impression that the government's orders had legal force for the period of suspension? On this reading an order suspending the effect of the court's judgment features not as a tool for controlling its legal consequences but as a mask obscuring its true nature. ${ }^{20}$

Later I will suggest that the Supreme Court asked itself the wrong question in Ahmed (no 2) and that it did so because of the distorting shadow case by the standard theory. Before doing so, however, I am going to illustrate two other ways in which the theory falls short. The first has to do with the force of unlawful administrative action prior to court intervention and the second with the effect of provisions that oust the court's capacity of review.

\section{EFFICACY AND ONTOLOGY}

Perhaps the most obvious problem for the defender of the standard theory has to do with the fact that unlawful administrative decisions have, unless and until challenged in the courts, the same force as lawful decisions. As Lord Radcliffe noted in Smith v East Elloe Rural District Council:

An order, even if not made in good faith, is still an act capable of legal consequences. It bears no brand of invalidity upon its forehead. Unless the necessary proceedings are taken at law to establish the cause of invalidity and to get it quashed or otherwise upset it will remain as effective for its ostensible purpose as the most impeccable of orders. ${ }^{21}$

First then, unless the courts take action in relation to an unlawful decision it will continue to have the full force of a lawful decision. If Ridge, for example, had never challenged his dismissal then the decision of the watch committee would have

\footnotetext{
18 Ibid. at para. [8]

19 Ibid. at para. [1]

20 This analysis is corroborated by Forsyth: "For the majority, once the court has in the exercise of its judgment concluded that an order is invalid then it is known to be void; and it would obfuscate the effect of that judgment to seek by the exercise of remedial discretion to vivify the void act." See C.F. Forsyth, 'The Rock and the Sand: Jurisdiction and Remedial Discretion' (2013) 18 Judicial Review 360-378, 372 21 Smith v East Elloe Rural District Council [1956] A.C. 736, 769-770
} 
successfully ousted him from his employment. It would have been as effective in this regard as a decision that had properly complied with the requirements of natural justice. ${ }^{22}$ Second, until the court sets aside an unlawful decision it will determine the legal situation of those subject to it: the assets of the claimants in the Ahmed saga, for example, were effectively frozen and remained so until the relevant secondary legislation was challenged. The effects of illegality, in other words, only manifest when we reach the courtroom.

This fact is further illustrated by the case of F. Hoffmann-Law Roche E Co.AG $v$ Secretary of State for Trade and Industry. ${ }^{23}$ Here a company challenged a government order requiring it to lower the price of certain drugs that it sold. When the company refused to reduce its prices pending judgment on the lawfulness of the Order the Secretary of State sought an interim injunction to prevent it from charging the full amount. Both the Court of Appeal and House of Lords agreed that the injunction ought to be granted. Speaking with a different voice from that with which he delivered Ridge $v$ Baldwin Lord Reid here held that "an order made under statutory authority is as much the law of the land as an Act of Parliament unless and until it has been found ultra-vires." 24

How to square these facts with the notion that an unlawful act is, from the moment of its inception, invalid? What sense, in other words, is to be made of an invalid-because-unlawful decision that nonetheless has, until challenged, all of the consequences of a valid decision? Two arguments have been advanced which attempt to clear the way for the standard theory in this regard, the first involving the suggestion that invalidity is a "relative concept".

Wade and Forsyth begin their analysis of unlawful decisions by acknowledging that the courts will declare invalid "an order only if the right remedy is sought by the right person in the right proceedings and circumstances." Given this, they continue, an unlawful order "may be 'a nullity' and 'void', but these terms have no absolute sense: their meaning is relative, depending upon the court's willingness to grant relief in any particular situation." 25 The notion is that whilst an unlawful administrative act is invalid simply by virtue of its unlawfulness this attribution only has "meaning" relative to the decision of the court. ${ }^{26}$ In this way it is

\footnotetext{
22 As Lord Morris made clear "If the appellant had bowed to the decision of the watch committee and had not asserted that it was void, then no occasion to use [the] word would have arisen." See Ridge v Baldwin [1964] A.C. 40, 125

${ }^{23}$ F. Hoffmann-La Roche \& Co.AG $v$ Secretary of State for Trade and Industry [1975] A.C. 295

24 See ibid., esp. pp. 322 and 341. Although cf. $R v$ Wicks [1998] A.C. 92 at 116 for Lord Hoffmann's contrasting interpretation.

25 See, H.W.R. Wade and C.F. Forsyth, Administrative Law, p. 251. The analysis is corroborated in P.P. Craig, Administrative Law, p. 739-740. The genesis for the view is to be found in H.W.R. Wade, 'Unlawful Administrative Action: Void or Voidable? (Part I)’ (1967) 83 Law Quarterly Review 499, pp. 512-518.

26 So Taggart says, for example, that Wade viewed "administrative action as void from its inception - 'hypothetically a nullity' in his words - and that this principle is
} 
necessary for the court to pass judgment in order to make sense of the ascription of invalidity.

This argument is then combined with a second claim: that unlawful but unchallenged decisions are factually but not legally efficacious. Forsyth says, for example, that whilst unlawful acts are "undeniably non-existent in law" they "do exist in fact." In turn, "that factual existence may be perceived as legal existence; and individuals may understandably take decisions on that basis." 27 In this sense, "unlawful activity may (and does) have effects." 28 These two elements, then, are intended to explain how a decision that is invalid ab initio nonetheless has effect - in fact but not law - unless and until set aside by a court - because the attribution of invalidity only makes sense relative to the judgment of the court.

What are we to make of these arguments? The first fails because the claim that invalidity is in the sense specified a "relative concept" is inconsistent with the notion that invalidity is a property of unlawful decisions. To say that a decision is invalid by virtue of its unlawfulness is to say that invalidity manifests at the point at which the unlawful decision is made because determined by this fact. We cannot hold both that the decision in Ridge's case was invalid because it was unlawful and that its invalidity could only be made sense of given the judgment of the court.

Consider the following analogy. There is a debate in philosophy about whether colours are properly speaking aspects of the world - i.e. as genuine properties of tables, mountains and books - or depend upon the characteristics of observers, as psychological properties of their visual experiences. The argument is about whether we say that the sky is blue because it itself has that colour or because we perceive it to be that way. Now whatever one thinks about the soundness of these two positions it is clear that they are inconsistent. The former admits that colours exist independently of the experiences of observers, and the latter does not. And just as the blueness of the sky is either an aspect of the stratosphere or else it is dependent upon the psychology of those observing it, so too invalidity is either a property of unlawful decisions or else the ascription of the concept depends upon the court passing judgment to such effect. You cannot have it both ways.

What of the notion that unlawful decisions have, until the court pronounces on them, "factual" but not legal existence? The problem with this argument is that such decisions have definite legal consequences. In fact, until the court passes judgment, they have all of the legal consequences of lawful and hence valid decisions. An overlooked aspect of Ridge $v$ Baldwin helps to illustrate the point. Ridge brought his case not because he wished to return to his former employment but

rooted in the absolute theory of invalidity. Unlawful administrative action is... accepted or treated as valid until successfully challenged, whereupon the 'hypothetical' voidness [of the act] is recognized." See M. Taggart, 'Rival Theories of Invalidity' in M. Taggart (ed), Judicial Review of Administrative Action in the 1980's : Problems and Prospects (Auckland 1986), 89

${ }_{27}$ C.F. Forsyth, 'The Metaphysics of Nullity', p. 144

28 Ibid. p. 146 
because he wanted to be able to resign from his position. Doing so would save him his pension rights, which would be forfeited in the case of dismissal but not in the case of resignation. So whilst Wade says that prior to the judgment of the court the watch committee were only "in authority" in the sense that they had "the physical power to exclude the old chief constable from the force...." their capacity to deprive Ridge of his pension was quite clearly a legal and not merely "physical" power. ${ }^{29}$ Indeed, it was Ridge's whole complaint that the committee had withdrawn certain of his legal rights in circumstances where they ought not to have done. ${ }^{30}$

This is not an isolated point about pension rights for the decision of the watch committee had, until set aside, all of the consequences of a lawful decision. Ridge was removed from office, the rights attached to that office were rescinded and a successor could be appointed. Now what the defender of the standard theory will want to say of such a decision is that it had these consequences because of its "factual", and not legal, existence. But what it is for a decision to exist in the legally relevant sense is for it to have the legal consequences that it claims for itself. This is exactly what the decision of the watch committee had, and would continue to have, until set aside by the courts.

It is harder still to see how the result in F. Hoffmann-Law Roche can be accommodated within the bounds of Wade and Forsyth's analysis. Here, it is worth recalling, the court issued an injunction upholding the effect of the government's order pending determination of its lawfulness. An injunction being a remedy designed to prevent a body from acting in breach of the law, the natural explanation of the result in this case is that the government's order had legal effect until pronounced upon by a competent court. 31

Several judges and commentators have, however, attempted to suggest an alternative reading of F. Hoffmann-Law Roche, one which is more in line with the orthodox view. Drawing on language used by Lord Diplock in that case they have suggested that the court, in granting interim relief, does not do so so as to enforce a legally valid decision but instead works on the basis of an evidentiary "presumption of validity." 32 Lord Hoffman says, for example:

${ }^{29}$ H.W.R. Wade, 'Unlawful Administrative Action (Part I)’ (1967) 83 Law Quarterly Review 499, p. 516

30 This much is shown by the fact that had Ridge not challenged the decision via judicial review within the appropriate time limit he would not have been able to proceed directly with a claim relating to his pension rights, collateral challenge being available only when issues going to unlawfulness are raised as a defence.

31 This explains why, even if the relevant order had turned out to be unlawful, the court would have been justified in granting such a remedy.

32 The relevant sections of Lord Diplock's speech are to be found in F. Hoffmann-La Roche \& Co.AG v Secretary of State for Trade and Industry [1975] A.C. 295 at pp. 366-367. See, for this interpretation, $R v$ Wicks [1998] A.C. 92 at p. 115, Boddington $v$ British Transport Police [1999] 2 A.C. 143 at p. 155 and pp. 173-174, M. Elliott, J. Beatson and M.H. Matthews, Beatson, Matthews and Elliott's Administrative Law : Text and Materials at pp. 85-90 and H.W.R. Wade and C.F. Forsyth, Administrative Law at p. 249. 
The [doctrine] to which Lord Diplock referred was in my view an evidential matter at the interlocutory stage and the presumption existed pending a final decision by the court. [He] was not putting forward the sweeping proposition that subordinate legislation must be treated... as valid until set aside. ${ }^{33}$

The notion is that the court, when acting in favour of the government at the interlocutory stage, works on the assumption that the latter's decision is valid. It is this evidentiary presumption rather than the legal force of the relevant measure that justifies the court in granting relief.

But because nothing can be done to displace the so called "presumption of validity" at the interim stage it functions not so much as a genuine rule of evidence, as is the case, for example, with the presumption of innocence but more as a rule of law, as with the so called "irrebuttable presumption" that children under 10 cannot commit crimes. And just as the latter rule helps to define the limits of criminal responsibility as opposed to adjudicating on evidential matters so too the rule in $F$. Hoffmann-Law Roche concerns the legal status of governmental action prior to court judgment not issues of proof. Indeed, it is worth remembering that the whole point of granting an injunction is to ensure that the law is respected. So it is only on the condition that the administration acts with legal authority that such a remedy is warranted in the first place.

\section{GETTING IN THE WAY OF JUDGMENT}

Neither the notion that validity is a "relative concept" nor the claim that unlawful decisions have merely "factual" existence succeeds in accommodating the effect of unchallenged decisions within the parameters of the standard theory. The former is inconsistent with the notion that invalidity is a property of unlawful decisions and the latter fails because of the legal and not merely factual significance of such acts. A second problem for the standard theory has to do with its inability to explain situations in which the courts are precluded from interfering with unlawful decisions, for example where statutory time limits exclude the possibility of challenge after a certain period or where aspects of the court's power of review are blocked from the start by an ouster clause.

Consider a statute which contains a clause preventing challenge to decisions concerning compulsory purchase after a six-week period. ${ }^{34}$ What would be the status of an unlawful decision issued under such a piece of legislation prior the passing of the limit? According to the standard theory there will exist in law no valid compulsory purchase order. The decision in question will be invalid at the point of and by virtue of its unlawfulness. What, then, is the defender of the theory to say about the situation after the six-week period?

\footnotetext{
${ }^{33} \mathrm{R} v$ Wicks [1998] A.C. 92, 115

34 As per, for example, The Acquisition of Land Act 1981
} 
On one interpretation because there was no valid order prior to the passing of the time limit so there is none after. But this view faces a yet more pressing version of the objection that we made to the standard theory's treatment of unlawful but unchallenged decisions. For whilst the latter kind of decision has the effect claimed for itself until challenged in the courts, decisions protected by time limits have legal effect in a way which is impervious to challenge in this way. ${ }^{35}$ If an unlawful decision concerning compulsory acquisition is not challenged within the mandated six-week period then the government has an unassailable right to take ownership of the property in question. The notion that decisions protected by time limit clauses are not themselves legally effective fails to capture this obvious reality.

Faced with this fact Wade suggested a different interpretation. Whilst unlawful decisions would initially count as invalid, he suggested, once the period in which the decision can be contested has passed "what was void must be treated as valid, being now in law unchallengeable." 36

[The] Act does not say that the order shall be valid: it merely says that it shall not be challenged in legal proceedings. But it is obvious that the only meaning of cutting off the remedy is to render valid what would otherwise be invalid. ${ }^{37}$

Applying this analysis to our example we can say that although the government would at the point of decision have issued an invalid compulsory purchase order, this would be validated after the fact at the expiration of the six-week period. The picture is one on which the passing of the time limit creates the legally binding act. ${ }^{38}$

The more natural understanding of time limit clauses is not that they play this constitutive role, however, but they act to prevent the courts from intervening to correct the effects of unlawfulness. What happens after the passing of the six week limit is not that a legally valid order comes into existence where previously there was none, but that an existing albeit vulnerable order is rendered invulnerable because

35 See, on this point, Smith v East Elloe Rural District Council [1956] A.C. 736, 750-751, 769-770 and $R v$ Secretary of State for the Environment, ex parte Ostler [1977] Q.B. 122, 135-136

36 H.W.R. Wade, 'Unlawful Administrative Action (Part I)' (1967) 83 Law Quarterly Review 499, 512

37 Ibid., p. 511

38 Elliott has suggested an alternate reading of Wade's argument in accordance with which he is not "contending that unlawful acts can become valid" by virtue of the passing of time limits: "Rather, [Wade] suggests that if it is impossible to challenge an act which is suspected of being unlawful, then it must be treated as valid." But for the courts to be under a duty to treat an administrative decision as legally biding is just what it is for what it is for that decision to be valid. For Elliott's argument see M. Elliott, J. Beatson and M.H. Matthews, Beatson, Matthews and Elliott's Administrative Law : Text and Materials, p. 92 
no longer subject to judicial review. The passing of the limit goes, in other words, not to the issue of validity but to the issue of access.

To see that this is so compare the way that time limits work in private law. When, for example, an individual is no longer able to bring a claim in contract because time barred they are preventing from suing on an existent but now ineffective contract. The clause does not touch upon the validity of the contract - it does not render an otherwise valid contract invalid - but goes to the ability of the claimant to have it enforced. Similarly, when a time limit runs out in public law such a clause prevents the individual from challenging a valid albeit vulnerable decision, but it does not render valid an otherwise invalid legal norm. The two situations are, in a sense, mirror images of each other - in the contract case a valid legal instrument is rendered ineffective by the time limit and in the administrative case it is rendered fully effective - but the principle is the same in either case: the issue is one of access, not validity.

How then to make sense of the effect of time limits and ouster clauses? The better explanation begins with the notion that they go to procedural and not substantive rights. When a six-week limit on the possibility of challenging an unlawful compulsory purchase order passes the ability of the individual to raise the issue of unlawfulness, and consequently the court's capacity to invalidate the order in question, is foreclosed. In the case of ouster clauses the same effect is achieved from the moment that the unlawful decision is issued; a legally effective but otherwise challengeable decision is placed beyond the reach of the courts. This shows how time limit and ouster clauses have the effect that they do simply by removing the possibility of challenge in the courts, allowing for a reading on which such clauses go to the issue of access as opposed to the issue of validity.

It should be noted that this conception of ouster clauses, much like our earlier discussion of the effectiveness of unlawful but unchallenged decisions, involves a transition. Whereas the standard theory relied on the notion that unlawfulness signals the invalidity of administrative acts, this alternative depends upon the idea that unlawful acts have effect in law unless and until set aside by a competent court. This explains both the legal effect of uncontested decisions - as valid but challengeable - as well as the effect of time limit and ouster clauses - as preventing the possibility of intervention. ${ }^{39}$ Unlawfulness on this conception specifies not the

\footnotetext{
39 It is true that the courts have historically been antagonistic to the use of ouster clauses and that one way in which they have denied such clauses effect is via the logic of the standard theory. In Anisminic the House of Lords held that a clause designed to prevent the courts reviewing the determinations of a statutory body applied only to lawful and hence valid decisions. "'Determination'”, Lord Reid said, "means a real determination and does not include an apparent or purported determination which has no existence in the eyes of the law because it is a nullity." In pronouncing a decision of the latter kind to be unlawful, the court held, it was not questioning a real determination by that body, only noticing that none existed. But this destructive logic which cuts against the possibility of an ouster clause of this type having any effect - essentially writing it out of the statute by other means -
} 
invalidity of an administrative act, but a requirement on the part of the court to invalidate it.

\section{THE DUTY TO INVALIDATE UNLAWFUL DECISIONS}

The debate about the status of unlawful administrative acts has been in various ways obscured by terminology. Following the revival of an old distinction by Lord Denning a number of authors have posed the question in terms that have their roots in the law of contract. ${ }^{40}$ The issue, they suggest, is whether unlawful administrative acts are to be classified as "void" or "voidable"?41 The standard theory is intended to encapsulate the notion that such acts are "void", whereas the claim that they are "voidable" specifies the alternative. And whilst the former attribution makes sense just as a void contract is no contract at all, so an unlawful administrative decision is understood to be no decision at all - the latter artificially constricts the range of alternatives.

The important point to note is that a voidable contract involves the notion of discretion. If a contract is, for example, formed on the basis of a material misrepresentation by one side then the other has the option to walk away. The transposition of language has lead to the impression being given that if unlawful administrative decisions are not held to be "void" then they must be "voidable", the latter option involving discretion on the part of the court about whether the decision in question should stand. So Wade says:

...perhaps the most important question of all is whether it is desirable, as the advocates of 'voidable' appear to wish, to use this conception for the purposes of making the law of judicial control more discretionary. Judicial discretion plays an indispensible part in the law. But it ought not to undermine the fundamentals. One of these, surely, is that the citizen may resist unlawful governmental action as of right. If this were a matter of

cannot itself count in favour of the standard theory. A theory should explain rather than, as the court did in Anisminic, explain away the law. See Anisminic $v$ Foreign Compensation Commission [1969] 2 A.C. 147, 170-171 as per Lord Reid. For discussion see H.W.R. Wade and C.F. Forsyth, Administrative Law, pp. 113-114

${ }^{40}$ Director of Public Prosecutions v Head [1959] A.C. 83, 112. See, on the history of the usage of these terms in public law, P.P. Craig, Administrative Law, p. 746

${ }^{41}$ Elliott, for example, suggests that the following is the fundamental issue: "Is unlawful administrative action void or voidable? ... If action is voidable, then it is to regarded as perfectly valid unless and until set aside by a competent court... However, if unlawful action is void, then it is invalid simply by virtue of its unlawfulness." M. Elliott, J. Beatson and M.H. Matthews, Beatson, Matthews and Elliott's Administrative Law : Text and Materials, p. 79. See also H.W.R. Wade and C.F. Forsyth, Administrative Law, pp. 254-255, Ridge v Baldwin [1964] A.C. 40, 125-126 and Boddington v British Transport Police [1999] 2 A.C. 143, 153-157 
discretion, the court would be taking upon itself the power to dispense public authorities from observance of the law. ${ }^{42}$

Rejecting an analysis of the law in terms of the "voidability" of unlawful decisions appears to necessitate an analysis of the situation in line with the standard theory.

These, however, are not the only options. Whilst the standard theory is motivated by a connection between the concept of unlawfulness and the concept of invalidity where the former is taken to imply the latter, there is another way of specifying the relation between the two which does not result in a general discretion on the part of the courts. Instead of saying that unlawfulness entails invalidity we can say that unlawfulness implies a duty on the part of the court to invalidate unlawful administrative action. ${ }^{43}$ As such, invalidity should be considered the law's response to the fact of unlawfulness; anything less would indeed involve a derogation from the court's basic duty to uphold the law.

Such a response on the part of the court is of course conditional upon the right issue being raised by the right person within the right timeframe. In this way the requirements of standing and judicial review procedure form conditions on the duty to invalidate unlawful decisions. If, for example, a court comes to the conclusion that the individual before them does not have standing to challenge a particular decision then that decision will remain effective because a condition on the court having jurisdiction to invalidate it - the requirement that the complainant bear an appropriate relationship to the unlawfulness alleged - will not have been met. ${ }^{44}$

This conception of administrative unlawfulness differs in a number of important ways from that suggested by the standard theory. First, because unlawfulness is taken not to signify the invalidity of an unlawful decision but a duty on the part of the court to invalidate it, such a decision will have the effect claimed for itself unless and until the court intervenes. Indeed, the existence of a duty to invalidate unlawful decisions presupposes the validity of the decisions to which it applies. In this way the account accommodates Lord Radcliffe's observation that

42 H.W.R. Wade, 'Unlawful Administrative Action: Void or Voidable? (Part II)' (1968) 84 Law Quarterly Review, 110. See also ibid. 110-114 and C.F. Forsyth, 'The Metaphysics of Nullity', pp. 141-142.

${ }^{43}$ It is important for these purposes that the courts are clear about the concept of an unlawful decision. As David Feldman has recently emphasized, an unlawful failure to give reasons in the aftermath of an administrative act, for example, should not result in the court invalidating the initial decision but in their requiring the administration to make public the grounds for it. It is only in the context where the unlawfulness bares properly on the decision in question that the appropriate response is to invalidate it. See D. Feldman, 'Error of Law and Flawed Administrative Acts' (2014) 73 The Cambridge Law Journal 275-314, 291 and 304-306 44 See, for example, Durayappah v Fernando [1967] 2 AC 377 
"unless the necessary proceedings are taken at law" an unlawful order "will remain as effective for its ostensible purpose as the most impeccable of orders." 45

Second, this understanding implies a picture of the court as an active agent in response to administrative unlawfulness. Recall that on the standard theory the judge, in issuing a declaration or quashing order, does not render invalid an otherwise valid decision but makes clear that which is already true: that there was never any decision in the legally relevant sense. By way of contrast, on this conception, the court's decision makes a real difference to the rights and interests of those subject to administrative action. This explains why in Ridge's case the court's judgment was needed to return to him the pension rights he would otherwise have been denied. It also explains how time limit and ouster clauses have the effect they do, by preventing issues concerning legality from being raised in the courts and consequently maintaining in effect unlawful but now unchallengeable decisions.

It is sometimes suggested that the possibility of collateral attack - questioning the lawfulness of particular administrative decisions as part of a defence in criminal or civil proceedings - depends upon it being the case that unlawful administrative acts are invalid from the beginning as opposed to being overturned by the courts. Forsyth says, for example, that "when the matter is raised collaterally, the unlawful act is denied effect without it having been quashed by the court; how can this be unless the unlawful act is void?" 46 The answer is that collateral attack involves an alterative means, justified on rule-of-law-based grounds, by which the courts may consider the lawfulness of administrative action. For whilst it is true that administrative decisions may only be invalidated by courts which have the capacity to issue public law remedies this does not preclude others from considering issues relating to their legality. Indeed, the very fact that collateral attack takes effect by way of defence presupposes rather than denies the validity of the unlawful measures to which it applies. A defence is only necessary, after all, in the context where an individual has committed a legal wrong, and the grounds for such a wrong may only be furnished by a valid as opposed to an invalid administrative act.

An understanding of administrative action specified in terms of the judicial duty to invalidate unlawful decisions explains both the force of unlawful but

\footnotetext{
45 Smith v East Elloe Rural District Council [1956] A.C. 736, pp. 769-770. Michael Taggart's important contribution to the debate on administrative unlawfulness takes us partway to this conclusion. He tells us that "a decision tainted by jurisdictional error" ought to be viewed as "valid and effective in law unless and until it is retrospectively invalidated." But his account leaves open whether the courts are under a duty to invalidate such decisions as well as the basis for their interim validity. It is also unclear about the extent to which Taggart means what he says when he suggests that the courts ought to treat unlawful decisions as retrospectively invalid i.e. as never having existed, legally speaking. A large part of his argument involves showing that the courts do the opposite i.e. that they recognize the prior validity of such measures in being, for example, properly the subject of appeal. See M. Taggart, 'Rival Theories of Invalidity', pp. 90-93

46 C.F. Forsyth, 'The Metaphysics of Nullity', p. 157
} 
unchallenged decisions as well as the effect of mechanisms that put a stop to the courts capacity to respond to illegality. Later I will argue that such an account also affords a better understanding of the contexts in which the courts have the power to moderate the immediate effect of a finding of unlawfulness. But first it is worth pausing to notice that the account faces an obvious and, if true, decisive objection. The argument is that the notion of unlawful but nonetheless valid administrative power is contradictory because it suggests that administrative bodies have the legal capacity to make decisions beyond the limits of their own powers. In the next section I will try to show that this paradox is more apparent than real.

\section{RESOLVING THE PARADOX}

In order to see the argument in its strongest form we should distinguish between common law and statutory conditions on lawful administrative action. ${ }^{47}$ In Ridge's case, for example, the duty to give a hearing was a judicial rather than legislative imposition, designed to regulate the use of the statutory power of dismissal granted to the watch committee. In a case such as this, where the administration has breached only common law constraints on the use of its power, the conditions in the relevant empowering legislation will not themselves have been violated and so there is a clear basis in the law for the decision to stand unless and until the court intervenes. What, however, of situations in which the administration has misinterpreted the very conditions that empower it to act in the first place? Surely the only possibility here is to hold that the body in question has acted in a way that has no legal effect? ${ }^{48}$

Consider, in this regard, the finding of unlawfulness in Ahmed (no 1). Whilst the Al-Qaida Order was found wanting for reasons of natural justice, the Terrorism Order was considered by the Supreme Court to be ultra vires the provisions of the United Nations Act. How can such a determination be both beyond the powers of the administration, i.e. outside of the scope of the empowering legislation, but nonetheless valid until challenged in the courts? This is possible, I will suggest, because administrative authorities share with other legal institutions a specific capacity: the power to interpret their own jurisdiction.

It may be helpful to see this aspect first in a different context. Consider the situation of an inferior court duty-bound by the ruling of a more senior court, as is the case where the Supreme Court has issued a ruling which binds the Court of Appeal. Here the Court of Appeal has a duty to follow the judgment of the Supreme Court, and in this sense it has no power to depart from the higher court's decision. However, if it errs in its understanding of the law by, for example, misinterpreting

\footnotetext{
${ }^{47}$ For ease of exposition I am setting aside cases in which the administration has power under the prerogative. The same analysis applies as in the statutory case, however.

48 For those who support the ultra vires theory of judicial review - in accordance with which all conditions on the lawful exercise of statutory power are to be found in the relevant statute - all forms of administrative unlawfulness will go to this stronger objection.
} 
the ruling of the latter its decision will nonetheless bind the parties to the case. In this sense, the Court of Appeal has the power - that is, the normative capacity to alter the rights and obligations of those before it - to act on the basis of its own understanding of its powers. ${ }^{49}$ This marks the court out as an authority within the legal system as it has the capacity to make to binding determinations about the law in front of it including that which regulates its own role. ${ }^{50}$ The court has, in other words, the power to interpret its own jurisdiction. ${ }^{51}$

What I want to suggest is that this power of interpretation carries over into the administrative context as a defining feature of public as opposed to private power. In the context of private law individuals have no capacity to interpret the limits of, for example, their power to contract. If they fail to abide by the conditions on the exercise of this power then their act will not have the consequences claimed for itself. By way of contrast, when the administration acts on the basis of its own interpretation of the conditions that empower it to act, its decision will have legal effect because it has the power to make binding determinations about the scope of its own jurisdiction. ${ }^{52}$

Despite the fact that it was ultra vires, then, the Terrorism Order had the effect claimed for itself because based on the government's interpretation of the pertinent Security Council resolutions as made relevant to its jurisdiction by the United Nations Act. The fact that it erred in its understanding of these requirements is an issue that went not to the validity of the government's decision - because it had

${ }^{49}$ Kelsen was one of the first authors to see this phenomenon clearly. See H. Kelsen, Pure Theory of Law (M. Knight tr, Berkeley 1967), 267-270.

50 Joseph Raz highlights this point by contrasting the role of the courts and legal subjects as interpreters of the law: "The difference between a court and a private individual is not merely that courts are provided with better facilities to determine the facts of the case and the law applying to them. Courts have power to make an authoritative determination of people's legal situation. Private individuals may express their opinion on the subject but their views are not binding." See, J. Raz, The Authority of Law : Essays on Law and Morality (2nd ed., Oxford 2009), 108 and more generally 105-111

51 The story is complicated by the fact that many senior courts not only have the power to interpret their own jurisdiction, but also to deliberately change certain aspects of their jurisdiction. A good example of the latter phenomenon is evidenced in the statement made by Lord Gardiner in 1966 where he declared that the House of Lords would henceforth have the capacity to depart from its own rulings in order to achieve justice. See The Practice Statement [1966] 3 All E.R. 77

52 As Raz notes: "The fact that a [body] may make a binding decision does not mean that it cannot err. It means that its decision is binding even if it is mistaken. My declaration of the legal situation is not binding at all because it is not binding if it is mistaken. To be a binding application of a norm means to be binding even if wrong, even if it is in fact a misapplication of the norm." See J. Raz, The Authority of Law, p. 108 
the power to interpret its own jurisdiction - but to the question of whether the courts ought to step in to invalidate the order it made. 53

How does this analysis help to respond to the objection that an account specified in terms of the judicial duty to invalidate unlawful decisions contains a contradiction? It does so by showing that the concept of power which features in each aspect of the accusation is different. It is only a contradiction to say that a body has the power to act beyond the limit of its own powers if the expression is used to signify the same concept in each context, but the argument just outlined shows that it is not. An administrative body has the power - in the sense of the capacity to alter the rights and obligations of those subject to its decisions - to act on the basis of its own interpretation of its jurisdiction. In turn, the courts are duty bound to invalidate decisions that proceed on the wrong jurisdictional basis, these being decisions which are outside the scope of the administration's power in the second sense. This shows how, even in cases where they fail to meet the conditions on the use of their powers, the administration may act in a way that has legal force. The category of unlawful but nonetheless valid decisions proves not to be a contradiction, and so does not stand as an objection to an account of unlawfulness which depends upon the possibility.

The analysis of public power in terms of the capacity of administrative bodies to interpret their own jurisdiction allows us to understand how unlawful acts may nonetheless have the normative consequences claimed for themselves. But it also helps us to explain the limits of administrative power. For example, a "decision" made by a person who is not an administrative agent will not acquire even provisional validity because it does not count as institutional action of the right kind. ${ }^{54}$ So too, if the administration can claim no legal basis for its decision - that is, if it cannot point to some source of its authority - then it cannot be said to have acted on the basis of a genuine interpretation of its own powers. In such a case there will exist no provisionally valid decision and no protection for the relevant administrative body from direct claims that it has violated rights. This was the result of the celebrated judgment of Lord Camden in Entick $v$ Carrington and it remains good law to this day. 55

\section{A PLACE FOR DISCRETION}

\footnotetext{
53 It is worth pointing out that the fact that administrative bodies have such a power of interpretation says nothing about the extent to which the courts should be willing to defer to them in their initial understanding of the law.

54 As Kelsen says: "It is undeniable that there are cases where something, especially a command which claims to be a legal norm, need not be so regarded by anybody... without, in fact, an order of nullification rendered by a special organ being necessary - for example, if a patient in an insane asylum issues a 'statute'." See H. Kelsen, Pure Theory of Law, pp. 277-278

55 Entick v Carrington [1765] E.R. 807
} 
Having described and defended an alternative to the standard theory of administrative unlawfulness, I turn in this final section to reconsider the judgment of Supreme Court in Ahmed (no 2) as well as the wider question of remedial discretion in public law. It will be remembered that the question facing the court in that case was whether to suspend the effect of the decision it made in Ahmed (no 1).

Approaching the issue through the lens of the standard theory Lord Phillips concluded that it should not: the only result of such an order, he suggested, would be to give the false impression that the government's decisions remained valid in the interim. The question concerning whether the court ought to exercise its discretionary power became one about honesty.

But of course the question of whether the Supreme Court should have issued an order suspending the effect of its judgment was not a question about whether it ought to have engaged in deceptive behaviour. The real issue was whether the interests of the administration in maintaining the effect of certain unlawful measures - in the context of the Ahmed case, to continue their control over the assets of those designated as suspected terrorists - trumped both the rule of law and rights based concerns of those subject to such measures. Because both the Terrorism and Al-Qaida orders would continue to have the effect claimed for themselves until set aside, the court's capacity to suspend the effect of its judgment was one which one which would have allowed it to maintain the validity of the orders for the period of suspension. As such, the question that the court should have asked itself was not pace Lord Phillips - whether it would be right to issue an order which would give the impression that the government's orders would remain in force, but whether those orders really should have retained their effect for the time in question. ${ }^{56}$

The problems caused by the Supreme Court's analysis are not limited to the factual circumstances of its decision, however, for its reasoning cuts against the very logic underlying the discretionary power it was asked to exercise. To see this consider the following analysis of Lord Phillips' judgment offered by Forsyth:

Once an administrative act is found to be unlawful by the court its invalid status is clear whether or not a declaration or quashing order is made or suspended... The recognition that the remedies change nothing in law has an

\footnotetext{
56 Lord Hope who gave the minority judgment in Ahmed (no 2) went some way to achieving this task, although his judgment too involves a number of contortions. Having agreed with the majority that the Terrorism and Al-Qaida orders were of no effect in law he went on, nonetheless, to declare his support for the suspension of the court's order quashing them. In favour of this approach he cited the "practical advantage" to the treasury that such an order: "...would not be ignored by the banks and other institutions, which would continue to give effect to the prohibitions and obligations in [the Terrorism Order] and [the Al-Qaida Order] until they were directed otherwise by an order of the Court." This much is true of course, but the reason that the banks would not have ignored the government's orders until quashed was because until that time they would continue to have legal effect. See Ahmed (no 2) [2010] UKSC 5, [2010] 2 W.L.R. 378 at [21]
} 
impact on remedial discretion: if the grant of remedy changes nothing, the denial of the remedy changes nothing either... where there has been a clear finding of invalidity, remedial discretion has to some extent become redundant. Anything less than a declaration of invalidity would amount to an 'obfuscation' of that finding of invalidity. ${ }^{57}$

Because unlawful decisions are understood to be invalid from the start so a finding of unlawfulness rules out the possibility that an order suspending the effect of the court's judgment could make any legal difference. As Forsyth says, "if the grant of remedy changes nothing, the denial of the remedy changes nothing either." 58 The result of the analysis is that when the court concludes that the administration has acted unlawfully the power to suspend the effect of its judgment becomes redundant, legally speaking. 59

But, of course, it is only in the context of a finding of unlawfulness that the question of whether the court should suspend the effect of its judgment comes into play in the first place. If the administration had acted lawfully in issuing the Terrorism and Al-Qaida orders then the Supreme Court would have had no remedy to grant. As a result, the issue of whether it should have suspended the effect of its judgment would not have arisen. It was, then, only because the administration had acted unlawfully that the issue of suspension became a live one. And if, as the

57 C.F. Forsyth, 'The Rock and the Sand' (2013) 18 Judicial Review 360-378, pp. $373-$ 374

58 Ibid., p. 374

59 A similar analysis prevailed in the case of Secretary of State for the Home Department $v$ JJ. Here a statutory regime made provision for the court to give directions to the Secretary of State for the revocation or modification of unlawful orders made under the Act. The majority of the court held that the exercise of such a power was logically impossible, reasoning that since the Secretary of State had "no power to make [the order] in the first place, there is simply nothing to revoke." Lord Hoffmann, in dissent, had the better view: "The power to direct the Secretary of State to revoke or modify the order does not imply that the order was lawfully made. On the contrary, the power arises only if the order is found to have been flawed, that is to say, not lawfully made. Thus the grounds on which the judge refused to consider the exercise of the powers conferred... would simply write them out of the statute. But there seems to me no conceptual reason why Parliament should not say that if the exercise of a power is found to have been unlawful, the court shall have power to modify the order or direct the Secretary of State to modify it so as to make it lawful." See Secretary of State for the Home Department $v$ JJ and others [2007] UKHL 45, [2008] 1 A.C. 385 at [26] and [53] for Lord Hoffmann's dissent. For discussion of related issues see M. Elliott, 'Invalid Control Orders: Void or Voidable?' (2011) 70 The Cambridge Law Journal 22-24. 
standard theory suggests, there is no effective decision for the court to invalidate in such circumstances then the power that it has is meaningless. ${ }^{60}$

Understanding the logic of the court's power involves taking a different approach from that employed by the Supreme Court in Ahmed (no 2): unlawful decisions remain legally effective unless and until the courts carry through on their duty to invalidate them. Not only does such a view enable us to better understand the issues at stake in Ahmed's case - the question before the court was not whether it should have lent itself to a procedure designed to "obfuscate the effect of its judgment" but whether it ought to have exercised its discretion to maintain in effect the government's unlawful orders for the period requested - but it is the only attitude which makes conceptual sense of the power that the courts have to modify the effect of their judgments in this way. ${ }^{61}$

The possibility of a court acting to suspend the effect of its judgment depends upon the notion that unlawful administrative decisions are valid in the first instance. But is this power compatible with the notion that unlawfulness signals a duty on the part of the court to invalidate unlawful administrative action? Surely a discretionary power to maintain the effect of unlawful action is inconsistent with a judicial duty to invalidate it? The objection involves a misunderstanding of the relationship between power and duty. The court's power to suspend the effect of its judgment is not a power to refuse to invalidate the unlawful decision in question, but a power to

${ }^{60}$ For a recent attempt to square cases in which the courts suspend or modify the effect of findings of invalidity with the standard theory of administrative unlawfulness see V.S. Nadhamuni, 'Suspending Invalidity While Keeping Faith with Nullity: An Analysis of the Suspension Order Cases and their Impact on our Understanding of the Doctrine of Nullity' [2015] Public Law 596-613. Nadhamuni suggests that such cases function as an exception to the general rule that unlawful acts are "null and void". By suspending the effect of a judgment declaring an administrative act to be unlawful, she suggests, the court creates "a voidable act". But an order suspending the effect of the judgment of the court is one which delays legal change as opposed to itself making a difference to the law. Nadhamuni's argument falls short for the same reason as Wade's treatment of ouster and time limit clauses. In both cases the effect of the relevant provision - the clause, the exercise of the power to suspend - is to disable the court from intervening to affect the law as opposed to affecting the law itself. See ibid. p. 602 and pp. 609-613 ${ }^{61}$ Ahmed (no 2) [2010] UKSC 5, [2010] 2 W.L.R. 378 at [8]. It is worth noting that the capacity of the courts to suspend the effect of their judgments appears not only as a part of their normal jurisdiction under the civil procedure rules but also as an explicit aspect of certain statutory regimes. The devolution arrangements, for example, all contain provisions allowing the courts to suspend the effect of judgments declaring legislation made under these regimes to be ultra vires. In the case of Salvesen $v$ Riddell the Supreme Court did exactly this, maintaining in effect a statute of the Scottish Parliament which violated the European Convention on Human Rights. See Salvasen $v$ Riddell [2013] UKSC 22 at [52]-[58] and for discussion M. Elliott, 'The Legal Status of Unlawful Legislation' [2013] Public Law for Everyone 
determine the point in time at which their judgment invalidating the relevant administrative act should take effect. If, for example, the Supreme Court had issued an order suspending the effect of its judgment in the Ahmed case this would not have involved a derogation from its duty to invalidate the unlawful orders, but a decision about when its judgment in fulfilment of that duty should be given effect to. A suspending order modifies but does not cancel the court's fundamental duty. ${ }^{62}$

What, however, of the more general understanding of remedies in public law as discretionary?63 Whilst an order suspending the effect of the court's judgment does not cancel its basic duty surely the refusal to grant a remedy, and resultant failure to invalidate the unlawful measure in question, would? The answer is that it would and that this is one reason to be cautious about the exercise of discretion in this area. ${ }^{64}$ Because the courts' duty to invalidate unlawful decisions features as one side of a coin, the other being that the administration has its powers conferred and regulated by law, so a failure to grant a remedy counts, in this sense, as a failure to uphold the law. This is not to deny that the courts sometimes have good reason to depart from their general duty to apply the law. Nor is it to deny that they have, in this context, the jurisdiction to do so. ${ }^{65}$ But here is a need to recognize what "is and should be the rule." 66 The duty to invalidate unlawful decisions must represent the starting point; as Wade reminds us, the courts should think long and hard before "[dispensing] public authorities from observance of the law." 67

62 Whilst there is no logical conflict between the court's duty to invalidate unlawful decisions and the power to suspend the effect of its judgment relating to such issues, there remains the possibility that too liberal an invocation of the latter would act so as to frustrate the practical effect of the former. As such, the courts should be reticent to use such a power.

63 See, on this issue, P.P. Craig, Administrative Law, pp. 746-749 and H.W.R. Wade and C.F. Forsyth, Administrative Law, pp. 249-251

${ }^{64}$ As Wade and Forsyth put the point "There are grave objections to giving the courts discretion to decide whether governmental action is lawful or unlawful: the citizen is entitled to resist unlawful action as a matter of right, and to live under the rule of law, not the rule of discretion" H.W.R. Wade and C.F. Forsyth, Administrative Law, p. 596.

65 For a recent example of the courts exercising remedial discretion in the aftermath of a finding of unlawfulness see R. (Hurley and Moore) $v$ Secretary of State for Innovation, Business and Skills [2012] EWHC 201, [2012] H.R.L.R. 374

66 P.P. Craig, Administrative Law, p. 747

${ }^{67}$ H.W.R. Wade, 'Unlawful Administrative Action (Part II)' (1968) 84 Law Quarterly Review, p. 110. So we should resist Feldman's view that in deciding whether to invalidate unlawful administrative acts the courts ought to balance the "principle of legality" against a range of other considerations, including the requirement to achieve "sensible, morally justified outcomes where interest conflict." The law, for the courts, must count as more than just one consideration among many. See D. Feldman, 'Error of Law and Flawed Administrative Acts' (2014) 73 The Cambridge Law Journal 275-314 esp. p. 285 and pp. 310-312 


\section{CONCLUSION}

In this paper I have argued against the standard theory of administrative unlawfulness. That theory, which holds that unlawful administrative acts are invalid by virtue of their unlawfulness, fails for the reason that such measures have the legal effect claimed for themselves unless and until set aside by the courts. A better theory starts with the notion that unlawfulness signals a duty on the part of the courts to invalidate unlawful decisions. In this way the analysis of administrative unlawfulness reminds us of the enduring importance of judicial review. 